\title{
The feeling of hope in cancer patients: an existential analysis
}

\author{
O sentimento de esperança em pacientes com câncer: uma análise existencial \\ El sentimiento de esperanza en pacientes con cáncer: un análisis existencial
}

\author{
Catarina Aparecida Sales ${ }^{1}$, Marissa da Silva Cassarotti ${ }^{1}$, Kelly Cristine Piolli ${ }^{1}$, Laura Misue Matsuda ${ }^{1}$, Julia \\ Wakiuchi $^{1}$
}

This study aimed at unveiling the feeling of hope in people who experience cancer in their existence. Qualitative study based on Heidegger's phenomenology, performed with eight cancer patients assisted in a philanthropic organization, between December 2013 and February 2014, in a northwestern city in Paraná, Brazil, using the following guiding question: "How do you perceive the feeling of hope at this time in your life?" The analysis resulted in the ontological themes: searching for hope in dealing with cancer, and experiencing feelings of hope and despair in being with others. Patients revealed mixed feelings, going from the lack of hope at the time of diagnosis to a rekindling of hope, as well as those who never lost the will to live. We conclude that living with cancer causes extreme feelings; and hope emerges as a feeling capable of influencing and causes an expressive impact in coping with that.

Descriptors: Hope; Neoplasms; Patient Care; Nursing.

Objetivou-se desvelar o sentimento de esperança para as pessoas que vivenciam o câncer em sua existência. Pesquisa qualitativa, fenomenológica heideggeriana, realizada com oito pacientes atendidos em instituição filantrópica, entre dezembro de 2013 a fevereiro de 2014, em uma cidade localizada no noroeste do Paraná, Brasil, inquiridos por meio da questão norteadora: “Como você percebe o sentimento de esperança neste momento de sua vida?" A análise emergiu nas temáticas ontológicas: buscando esperança no conviver com o câncer e vivenciando sentimentos de esperança e (des) esperança em seu estar-com o outro. Os pacientes revelaram sentimentos que transitam entre a falta de esperança no momento do diagnóstico e o reascender deste sentimento, além da expressão daqueles que não perderam a esperança em viver. Concluiu-se que conviver com o câncer fez os pacientes lidar com o extremo de seus sentimentos e a esperança foi capaz de influenciá-los e repercutir expressivamente em seu enfrentamento.

Descritores: Esperança; Neoplasias; Assistência ao Paciente; Enfermagem.

El objetivo fue desvelar el sentimiento de esperanza para las personas que vivencian el cáncer en su existencia. Estudio cualitativo, fenomenológico heideggeriana, con ocho pacientes atendidos en una institución filantrópica, entre diciembre de 2013 y febrero de 2014, en una ciudad del noroeste del Paraná, Brasil, inquiridos por la cuestión: “¿Cómo usted percibe el sentimiento de esperanza en este momento de su vida?". El análisis emergió en las temáticas ontológicas: buscando esperanza en el convivir con el cáncer y viviendo sentimientos de esperanza y (des)esperanza en su estar-con el otro. Los pacientes revelaron sentimientos que transitan entre falta de esperanza en el momento del diagnóstico y su reavivar, además de expresión de aquellos que no perdieron la esperanza en vivir. Convivir con el cáncer hizo los pacientes lidiaren con el extremo de sus sentimientos y la esperanza fue capaz de influirlos y repercutir expresivamente en su enfrentamiento.

Descriptores: Esperanza; Neoplasias; Atención al Paciente; Enfermería.

\footnotetext{
${ }^{1}$ Universidade Estadual de Maringá. Maringá, PR, Brazil.

Corresponding author: Catarina Aparecida Sales

Rua Bragança, 630, Apto 501, Jardim Universitário. CEP: 87020-220. Maringá, PR, Brazil. E-mail: casales@uem.br
} 


\section{Introduction}

For the human being, experiencing the disease is a unique experience, faced in a singular manner and according to the context of life and interpersonal relations of each one ${ }^{(1)}$. Besides that, when circumstantially transposing the loss of integrity of health to the diagnosis of a neoplasia, an uncertain and prolonged path is open, which weakens future plans and permeates the imminent possibility of death ${ }^{(2)}$. In those moments, the patient sees the world as a horizon of everyday experiences which can annihilate not only the particular things around him, but also his dreams of living pleasurable future.

However, throughout time we follow a continuous search of the human being for hope, as strength to keep on fighting against the disease. Hope, which can be defined as a subjective probability of good results, can provide meaning for the daily lives of people who pervade through diseases which threaten life, besides contributing to the welfare, satisfaction and adaptation to the factors of stress caused by the diseased ${ }^{(3)}$. It is considered fundamental for the survival of the person ${ }^{(4)}$. According to this idea, hope becomes a feeling able to make the human being with cancer look at the horizon of his life under a new perspective, believing that something is possible even when a chronical disease such as cancer comes into his life.

Hope is what pushes man to go ahead, once it sustains the opening to several possibilities of future when nourishing the capacity of dreaming and walking. Furthermore, this feeling influences the perception of the subjects concerning his quality of life, as well as the physical and psychological health and the health of social relations, and it can positively modify his vision on the disease $\mathrm{e}^{(5)}$. Consequently, hope has a beneficial effect in the health of people with neoplasia, once it strengthens their capacity to deal with situations of crises, in the determinations of healthy objectives, maintenance of the quality of life and promotion of health ${ }^{(6)}$.
So, because it is a phenomenon of relevant importance to the human being, especially in situations of crisis, there is the need of the nursing professionals to include in their planning of care, giving the due attention to the feeling of hope in his patient ${ }^{(7)}$. Independently of the stage of the disease, they tend to preserve some kind of hope rooted in their perception on the disease or in the mechanisms used to deal with this problem ${ }^{(8)}$.

Considering that hope is a fundamental link in the nursing care, researches which involve the theme concerning the lives of those patients can be reflected in nursing actions which awaken this feeling in them ${ }^{(9)}$. This need is especially imposed concerning the emotional storm experienced, once keeping this feeling can make the days of the sick ones lively, and strengthen his process of coping. Under this perspective the following question was established: How do the patients perceive the feeling of hope facing the personal experience with cancer? In consonance, this study had the objective to unveil the feeling of hope in people who experienced cancer in their lives.

\section{Method}

It is a qualitative study, with Heidegger's existential phenomenological approach. The choice of such approach was due to the fact that it provides the unveiling of the experienced feeling, widening the possibilities to exercise better nursing care, once it contemplates the subjectivity of the beings ${ }^{(9)}$. So, in an existential ontological sense, the region of the inquiry or ontological-ontic region was formed by the feelings of the patients, regarding hope in his being-in-theworld with cancer.

As subjects of this study, we chose patients with cancer assisted in a philanthropic institution in the northwestern region of Paraná, Brazil. It provides services of nursing, physiotherapy, psychology, drugstore, social service and legal assistance, and it is a social organization with non-profitable purposes. The patients registered in the above mentioned 
institution who lived in the same city, older than 18 years, knowing their personal diagnosis of cancer and with six months of diagnosis were included in the study. The period of six months was observed aiming at the possibility of a greater experience of the treatment and its repercussions in the hope of the patients. The criteria of exclusion were considered as follows: incomplete address to find the patient, as well as his death.

With the use of phenomenological approach, the researcher has a question and will go through it to reach its comprehension. With this objective, the researcher does not limit himself in the search of what, but how of his object of investigation, looking at the possibility of his movements of veiling and/or unveiling ${ }^{(10)}$. For such, we used as guiding question: 'how do you perceive the feeling of hope at this moment of your life?' The patients were interviewed at home by the researchers, and the data were kept in a digital recorder for a later transcript.

The number of speakers was established from the sufficiency of meanings found by the researcher in the daily way-to-be of the interviewees, which corresponded to the objective proposed by the research $^{(10)}$, that is, when the phenomenon under study showed itself in its essence to the researcher, making it possible for him to understand it and interpret it. In this study the meanings that supported the comprehension of the hope in patients with cancer, were reached through eight interviews. This perception was possible because the analysis were made concomitantly to the data collection.

In order to capture the plenitude expressed by the subjects in their languages, we chose the individual analysis of each report. In this procedure, close readings of each report a priori, separating the excerpts or units of senses (us) which, for us, showed to be fundamental structures of the existence of the interviewed participants ${ }^{(11)}$. We started to analyze the units of sense of each report a posteriori, making a phenomenological selection ${ }^{(11)}$, which originated the ontological themes: searching for hope in the experience with cancer and going through feelings of hope and hopelessness in his being-with-the-other. They were analyzed under the light of Heidegger's ideas, and also scholars on the theme and researchers who deal with the hope in chronic patients.

Because it is a research which involves human beings, we comply with all the legal and ethical precepts ruled by ordinance no. 466/2012 of the National Counsel of Health - Health Department. There was consent of the philanthropic institutions and approval by the Permanent Committee of Ethics in Research involving Human Beings of the Universidade Estadual de Maringá, PR, Brazil, under ordinance no. $147.721 / 2013$. In order to keep the anonymity to each deponent, we refer to them using (S1, S2, S3...S8).

\section{Results}

The results of this study came from eight deponents who experienced cancer in their lives. Of those, five were male and three female, the age range was 49 to 78 years. The occurrence of the cancer varied: throat, larynx, breast, lung, ovary, intestine, prostate and melanoma.

The comprehension of the reports revealed the mix of feelings of the patients which goes through the lack of hope at the moment of the diagnosis and the rekindling of feeling, besides the expression of those who did not lose the hope to live at any time.

\section{Searching for hope in the experience with cancer}

The diagnosis of cancer is an outstanding moment, once the subjects see a new challenge, understood in several different ways by each one. Not always hope comes facing this type of news, and it can be turned into a feeling of despair, as highlighted in the report as follows: No, hope I had none. When I heard the news I went all the way down. I was desperate, desperate! I panicked, the world was over for me, the world opened itself. This feeling is only ours, I know I panicked, I thought the world was going to end and I would never come back. You know, I lost all the hope (S4). 
Besides that, we can infer that during the disease and the treatment, despite the several mishaps experienced in their daily lives, the patients tend to glimpse at new perspectives: Without hope I had already died, because it is difficult to pass, it is very difficult to pass. This cancer, it's the same thing as if a guy comes to you and robs you, it's the same sensation. That sensation that you're doing to die there, now! You feel despair, you feel like going out and jumping out of the window. And, this moment, hope is gone, opened a hole and went away, until one day, you come back again (S4). Yes, we have hope, when we are bad, sick, and keep on living to see where we will go. Without hope the person becomes discouraged, and she goes on until she dies. Because, in the beginning, it was sad, but later on, it was getting better. We didn't know what could happen (S1). I spent three days without hope, afterwards, it was over. I know I will go away, if I don't' get over this disease, because even that I got over, it's finished. Because if my husband went, if so many people go, why not me? You know, on the other side, it's beautiful, it's another life and, so, I go on living, but with hope (S6).

There are, still, those who, even facing a fearful disease such as cancer, are able to look into the future in a positive way, without allowing that feelings of pain and defeat, beat them: My hope is to go on the way I am, in this pace, and then better. I never thought in a negative way, I always thought positively! You have to expect that tomorrow will be better! In this case, I had just made the surgery and I was recovering, if I thought I was going to die, I would be completely down, downhole. But I wasn't through because of that. On the day of the surgery, my wife was worried, my daughter too. But I got up as if I were going to a party (S3). I think it's all that happens in our lives, you have hope in something, to get better, and then hope is everything. Hope is a good thing (S7).

Amid the circumstances of the cancer, the patient searches for hope in a stronger force, and this, many times, is found through the valuation of her faith, or the belief in God: Everything trying to do the very best, the maximum, the possible, not only to please God, but also to have this zest for living. Certainly, I believe in God above and what the doctor says, there is a greater doctor being a person of God, I know I am blessed (S5). My hope is God, and the friends I have. And I say it again, nothing is better than God, nothing, only him. Because, who will I talk with? Because when I want to talk, I talk to God, only he can hear me, I don't have anything else. First I place God, that's how I think. It's my hope. Because the man upstairs is tough, He raises you, he pulls you (S6).

\section{Experiencing feelings of hope and hopelessness in his being-with-the-other}

The one, who has his life invaded by cancer, is also often influenced by the ones surrounding him, whether positively, or not. Some hear words of comfort and hope, but not only these words are uttered, as we can observe in the following reports: Then, all of those who come here with friendly words, but there are also the ones who come here to kill you. Some come here and say this to you: Gee, woman, you look alright! You know why? My neighbor was just like you, but she already died. Then comes another and says: Gee, woman, the person went to the church and God operated a miracle in her life and she was healed! She is healed, she never had it again. So, there are those that bring miracles that happen in life, fine things, and there are those who bring bitter words. So, you have to know how to separate the good things from the bad ones (S4). A person comes and says: Ah! You're going to die! You're going to die! We get discouraged. Othesr say: Ah, it's nothing, you will get well, I don't know what, and we get encouraged. It seems we get better, we don't keep that in our minds (S1).

Besides the reports coming from people surrounding these patients in their daily lives, they also experience a context permeated by hope, or glimpses of it, with the health professionals responsible for their care. So, they interfere through their words, in their experiences with the patients with cancer: Yes, when he told me about that cancer, we got desperate, but after the surgery we had some hope, it seems it was rather good, we keep on living, right? It's because the doctor said: Look, Mr. X, you don't have that anymore, so let's take care, make the treatment and you keep going to your appointments to take care. Because he said that cancer is a treacherous disease, it heals here and comes back there. So, you must have assistance. If was important for me to go to the psychologist for advice. I got encouraged and I am here until today. Yes, encouraged! And I have hope now to live some more time (S1). I try to live each day and, when I asked this to the doctor he was, like, categorical in saying: Look here, when it reaches this point, every 
malign cancer is unpredictable. So, your expectation of life will be the same, and, on top of that, of course that when we speak like that, the doctor says: $70 \%$ is left behind, 30\% have treatment, not cure, and they have treatment among those 30\%, according to the information of the doctors who assist me. So, only that gives me hope and comforts me, and through the emotional and spiritual part, I try to put it all together that I'm searching in the treatment (S5).

Among the troubles of being a bearer of an oncologic disease, the family, or a special family member, is presented as a fundament which drives to believing and continuing his path: I saw hope in my granddaughter. Because my former daughter-in-law was pregnant she was about to have a baby and she came in the hospital, hiding. I remember that I kissed her belly and said: You, daughter, grandma will be here, waiting for you. I lost (hope) in some moments, but when I saw my grand-daughter, hope would come back, like today, I look at her and say: You are my hope. I need you (S8). You already feel alone with the family, without the family and hope... I had already had... How is it called? It's depression. You have to get encouraged, because when depression comes, it doesn't go away anymore. So, the family is fundamental (S7).

This importance of the family is reaffirmed when the patient thinks in the welfare of the other who is near him, according to the following reports: If I don't have hope, if I don't get happy, people around me will be sad too, because they come with words to help me, and I am sad, they get sad too, right? (S4). Because my mother needs me, my son needs me and, when my daughter forgives me, she will need me and I want to be strong for this and for myself, because I need to take care of myself to take care of them (S6).

\section{Discussion}

The diagnosis of a disease such as cancer raises a diversity of feelings, especially the ones related to the worries and concerns on the future, that seems threatening and obscure when the diagnosis is established ${ }^{(12)}$. Facing so many uncertainties and woes, the patient gets lost in him and reveals different feelings and ways of acting, which shape his perception regarding the disease.
Under Heidegger's analytics, the disposition and the opening rise on the past, when man retracts himself, occasionally, to the world of forgetfulness, to his having-been-launched ${ }^{(13)}$. This disposition in characterized in the humor or in the affectivity representing the ways how man expresses in his howin-the-world under this analysis, the awe or the fear is characterized as an inadequate disposition, once it finds its reason in the beings who come to it, bringing with them a feeling of bad omen. The existential and temporal of fear is formed by the forgetfulness of oneself. Fear provides the removal of the being-there of his can-be more proper and, in this forgetfulness, he no longer recognizes himself in his surrounding world and does not visualize the several possibilities around him, because, in fear, man is disturbed facing the world, become distressed and troubled.

When analyzing the reports of the patients, we conclude that when the diagnosis of cancer comes. They go through moments of difficult apprehension of what is surrounding them. The feelings experienced by these patients make us understand that their hope, before founded in a pleasant future, seems to collapse with the news of the disease. So, the fear revealed in the reports is founded, at first, in a vigor of having been (past) healthy, once it threatens his presence from a concrete being, cancer, which disturbs his familiarity with the world to a point that he confuses his possibilities ${ }^{(14)}$. Entangled by this feeling, the patients have difficulty to discern the scenarios which are placed facing the facticity of the cancer and annihilate any feeling which brings them comfort.

However, opposing fear, hope characterizes a good future, that is, it brings with itself, the necessary strength, so that the patient can emerge from his anguish and glimpse at new possibilities ${ }^{(13)}$. In this context, hope acts as a stimulus to walk on, as a feeling which leads the human being to believe in positive results. In the several circumstances of life, this feeling keeps the perseverance in fighting even when there is no positive evidence during the journey ${ }^{(15)}$. 
According to this way of thinking, we discern that, after the storm of the diagnosis, at a certain moment, man begins to glimpse other possibilities, from a new opening to the world, and starts a trajectory in search of his treatment. Therefore, the feeling of hope is renewed, as shown in these reports: S1, S4 e S6, who loosened the bonds, imposed by cancer and understood that there is still hope for their lives.

There are still, among the patients who experienced cancer, those who entangled in a character of humor exalted, or exalting, which makes the beingthere forget the fear, staying with hope facing any adversity which may occur. Such characteristics lie, above all in having hope-for-himself, in a way which makes the patient carry to himself inside the hope and counteract to what is expected ${ }^{(13)}$.

For those patients who cling to the hope in order to overcome the maintenance of this feeling, providing subsides to deal with difficult situations during the disease. Along this path, the facts of feeling and offering love are highlighted, especially with the family, besides having targets for a short and for a long term range, keep autonomy until it is possible and also have a dose of good humor ${ }^{(16)}$.

Another way of hope was expressed by the patients through faith, once it was observed that some bring in themselves the belief that someone is watching over them, which characterizes hope as a possibility, proper of each one facing this line of thinking, we apprehended in the words of the deponents that faith can be fundamental in the search of meaning, purpose and transcendence to people who, when facing the end of life, feel touched in the care of their existence by something superior to what they experience ${ }^{(17)}$. Something which makes them glimpse the possibility of transcending their own existential anguish and discover, in them, renovating feelings.

The language is part of the ontological constitution of the being-there. The speech that comes from the other to us is communication. The ontological tendency of the communication is to make the listener participate in the message transmitted. So, speaking, in Heidegger's analysis, is the way of being of the understanding and of the being-in-the-world everyday life. Nevertheless, as a project, in speaking, the human being in himself , the ontological reference of what is said, that is, he never communicates himself in the way of a genuine adaptation concerning the real fact, is content with himself by repeating and passing on the $\operatorname{speech}^{(13)}$.

In this sharing of experiences, the words become a bridge which lead the patient to find hope, encouraging him or making him sad, when the difficulties of the disease are presented to him. This speech directed to the patient, without a reflection about its truth is understood as chatter. The chatter can intervene to the patient from knowledge that is acquired through comments from moments experienced in the interaction with family members and other circumstances along the disease ${ }^{(18)}$.

When discovering himself as dasein or beingin-the-world, man always finds himself as being-with (Mit Sein), being other (Mit Dasein) also a being-in-theworld, that is, a being for the others, a companion. And it is in this being-with-the-other that man visualizes the possibility of being with someone, not just as an object of care, but in an involving and significant manner ${ }^{(13)}$. So, in the several situations in which the patient is, he unveils, through his varied expectations, the need to receive a differentiated support from those who offer the health professionals ${ }^{(8)}$. Therefore, with a role of such seriousness with the patients with cancer, the ones responsible for the professional care, many times, have the power to dictate the thoughts of these beings and even bring them hope thanks to their manifestations of solicitude.

Amid this context of influences exercised by the one who cross the path of those who fight against cancer, the family is shown as a fundamental link. This family can grant hope to the patient by the fact that they are seen, present, assisting him. Therefore, besides the hope found in the relation with the 
health professional, the family support is revealed as help in the control of the situations to be faced, that is, experiencing cancer ${ }^{(7)}$. Furthermore, there is an existential duplicity of the being-with concerning the comprehension of the being-of-the-other, once man is capable to understand his own being insofar as the manages to understand the other ${ }^{(19)}$.

So, its comprehension drives the patient to look at the needs of the beings around him and perceive that not only he needs others, but they need him. Consequently, the one who suffers with cancer can have the feeling of hope lit by the relation with those who are part of his world loved by him, the health professionals and the family are beings of care, so it is up to them to be together with the patient, helping him to attribute an authentic sense to his existence, through gestures of comfort and attention ${ }^{(20)}$.

We observed that, along the way faced by the patient, he has other beings with relevant importance close to him, influencing him concerning the awakening of hope in his life, which is made possible by the encounter with the other. Such attitude can transform hope in a valuable instrument of care for these beings, once hope does not let the patient and his family members be weak facing the vicissitudes and lead them to join forces to beat the disease and reach cure $^{(2)}$.

The presence of the other, as a way to influence the patients to follow the path imposed, becomes unique for the patient and unveils a range of possibilities in his being-in-the-world with cancer.

Finally, it is reiterated that, facing the adversity which cancer imposes to the life of the patients under treatment, hope can be primordial to allow the glimpse of new possibilities, besides imparting strength to cope with the problem. When taking care of beings with cancer, we should not only consider the technical aspects, but, wisely, make use of sensibility, in order to understand and to provide total assistance to the patient ${ }^{(21)}$.

\section{Final Considerations}

Experiencing cancer makes the patients deal with the extreme of their feelings, sometimes experiencing the impact of the diagnosis and the treatments in their lives, sometimes in the attempt to pursuit strength to cope with such situation and overcome it. So, aimed the problems experienced after the disease, hope emerges as a feeling capable of influencing the vision of the patients facing cancer, and expressively reverberate in coping with it.

As beings-in-the-world, the oncologic patients remain surrounded by beings who participate in his life as promoters of possible feelings. The same way, these people can provide a painful vision of the moment the patient is going through, as well as his yearnings concerning the future situation amid cancer. The reports revealed this influence particularly through friends, family members and the health professionals who assisted the patients with cancer.

Facing this reality, we consider that, in the same condition of health professionals and promoters of welfare, we must be aware of our behavior and words directed to the other, once the influence exercised by us can be decisive in the unfolding of the feeling of hope of those we take care. According to this thinking, a study like this, which unveils the feeling of hope in patients with cancer, can contribute substantially for the assistance directed to these beings, in the sense of rethinking attitudes and orientations and of sheltering these patients in their fears, uncertainties and more intimate thoughts.

We consider necessary to point out the frailties of this research, which is restricted to the specificities of the interviewed deponents, as well as the coverage of the reality experience in their venues of treatment. So, we are aware that the results found herein must not be generalized. But we have the conviction that the assistance rendered must follow a though and an acting which contemplate the feelings here 
highlighted, in order to remedy any situation which depreciates the hope of these beings. Therefore, we hope that this study will serve as an incentive to new researches which enhance knowledge on this thematic even more.

\section{Collaborations}

Sales CA, Cassarotti MS, Piolli KC and Wakiuchi $\mathrm{J}$ contributed for the conception and planning of the research project, analysis and interpretation of data, writing, critical revision and final approval of the article to be published. Matsuda LM contributed for the critical revision and final approval of the version to be published.

\section{References}

1. Huff R, Castro EK. Repercussões emocionais do câncer ginecológico e exenteração pélvica. Rev Psicol Saúde. 2011; 3(1):33-42.

2. Lima LM, Bielemann VLM, Schuwartz E, Viegas AC, Santos BP, Lima JF. Adoecer de câncer: o agir e o sentir do grupo familiar. Ciênc Cuid Saúde. 2012; 11(1)106-12.

3. Jafari N, Farajzadegan Z, Zamani A, Bahrami F, Emami H, Loghmani A. Spiritual well-being and quality of life in Iranian women with breast cancer undergoing radiation therapy. Support Care Cancer. 2013; 21:1219-25.

4. Caboral MF, Evangelista LF, Whetsell MV. Hope in elderly adults with chronic heart failure. Concept analysis. Invest Educ Enferm. 2012; 30(3):406-11.

5. Duggleby WD, Swindle J, Peacock S, Ghosh S. A mixed study of hope, transitions, and quality of life in family caregivers of persons with Alzheimer's disease. BCM Geriatr. 2011; 11(88):1-12.

6. Orlandi FS, Pepino BG, Pavarini SCI, Santos DA, Mendiondo MSZ. The evaluation of the level of hope of elderly chronic kidney disease patients undergoing hemodialysis. Rev Esc Enferm USP. 2012; 46(4):900-5.

7. Pinto S, Caldeira S, Martins JC. A esperança da pessoa com cancro - estudo em contexto de quimioterapia. Rev Enferm Referência. 2012; 3(7):23-31.

8. Fonseca MFC, Cruz AG, Dias Neto DM. Expectations of patients during a hospitalization in a Palliative Care Unit. Rev Enferm Referência. 2012; 3(7):1918.

9. Chinchilla Salcedo, TC. ¿Qué significa la esperanza en padres de hijos con cáncer? Aquichan. 2013; 13(2):216-25.

10. Paula CC, Souza IEO, Cabral IE, Padoin SMM. Analytical movement - Heideggerian hermeneutics: methodological possibility for nursing research. Acta Paul Enferm. 2012; 25(6):984-9.

11. Josgrilberg RS. A fenomenologia como novo paradigma de uma ciência do existir. In: Porladeck DD. A fenomenologia do cuidar: prática dos horizontes vividos nas áreas da saúde, educacional e organizacional. São Paulo: Vetor; 2004. p.31-52.

12. Salci MA, Marcon SS. A convivência com o fantasma do câncer. Rev Gaúcha Enferm. 2010; 31(1):18-25.

13. Heidegger M. Ser e tempo. $6^{\mathrm{a}}$ ed. Petrópolis: Vozes; 2012.

14. Fernandes AFC, Bonfim IM, Araújo IMA, Silva RM, Barbosa ICFJ, Santos MCL. Significado do cuidado domiciliar à mulher mastectomizada. Esc Anna Nery. 2012; 16(1):27-33.

15. Galvão MTG, Bonfim DYG, Gir E, Carvalho CML, Almeida PC, Balsanelli ACS. Hope in HIV-positive women. Rev Esc Enferm USP. 2012; 46(1)38-44.

16. Ripamonti CI, Buonaccorso L, Maruelli A, Bandieri E, Boldini S, Pessi MA, et al. Hope Herth Index (HHI): a validation study in Italian patients with solid and hematological malignancies on active cancer treatment. Tumori. 2012; 98(3):385-92.

17. Asgeirsdottir GH, Sigurbjörnsson E, Traustadottir R, Sigurdardottir V, Gunnarsdottir S, Kelly E. "To cherish each day as it comes": a qualitative study of spirituality among persons receiving pallitive care. Support Care Cancer. 2013; 21:1445-51.

18. Melo MCSC, Souza IEO. Ambiguidade - modo de ser da mulher na prevenção secundária do câncer de mama. Esc Anna Nery. 2012; 16(1):41-8.

19. Ferreira AMC. Amor e liberdade em Heidegger. Kriterion. 2011; (123):139-58. 
20. Moreira RC, Sales CA. O cuidado autêntico ao ser com pé diabético sob o enfoque Heideggeriano. Ciênc Cuid Saúde. 2009; 8(4):515-22.

21. Oliveira GS, Bavaresco M, Filipini CB, Rosado SR, Dázio EMR, Fava SMCL. Experiences of the family caregiver of a person with intestinal ostomy due to colorectal cancer. Rev Rene. 2014; 15(1):10815. 